Saeculum Christianum

vol. XXIII (2016)

pp. $131-144$

\title{
BARBARA KOWALSKA
}

Jan Dlugosz University, Częstochowa

\section{JOHN OF CAPISTRANO IN JAN DŁUGOSZ'S ANNALES}

This figure should certainly be considered as an example of the phenomenon of wandering medieval preaching and its impact on mass religiosity - this is the sentence that crowns Agnieszka Lissowska's article on John of Capistrano's anti-Hussian mission ${ }^{1}$, correlating with other opinions of this type. Do the findings of the researchers of the great preacher who have at their disposal a fairly rich source legacy strengthen the work of Jan Długosz, Annals or chronicles of the famous Kingdom of Poland, containing a basic historiographic account of the preacher's stay in $\mathrm{Krakow}^{2}$ ? Is the metaphorical, didactic and ideological layer ${ }^{3}$ prevailing in the message, or is it the truth about the historical figure? The attempt to answer these questions is the author's task in this paper.

One of the chapters of the Annals ... referring to the year 1451 entitled Ioannes Capistranus Moravis contionatur, haeresim Hussitarum confutans et fulget variis miraculis ${ }^{4}$ (John of Capistrano preaches to the Moravians, repelling heresy and dazzles with various miracles) suggests that we are dealing with a writer who is also covering events of Central European countries $^{5}$. In the title, Dlugosz was straightforward about the subject of his considerations. By mentioning the miracles performed by John of Capistrano, he introduced us to the sacred atmosphere that he so eagerly created, inscribing it in numerous historical or only source paintings. The first sentence of the chapter argues that we will learn about the famous and venerable person, as indicated by the terms assigned to the preacher (vir celebris et venerandus). Epithets, whether in the form of adjectives or variatio sermonis, or in other words, usually emphasise not the casual, but characteristic feature of the character. In the work we are interested in, however, we do not notice the reservation of these terms to one person.

\footnotetext{
A. Lissowska, Antyhusycka misja Jana Kapistrana na Ślasku, in: Bernardyni na Ślasku w późnym średniowieczu, ed. J. Kostowski, Wrocław 2005, p. 63; further: Bernardyni na Śląsku... .

2 See: A. Zajchowska, Na marginesie. Nieznane świadectwo pobytu Jana Kapistrana w Krakowie?, in: Felix indiget amicis. Studia z dziejów kultury duchowej i intelektualnej średniowiecza ofiarowane Profesorowi Krzysztofowi Ożogowi, ed. W. Świeboda, M. Zdanek, Kraków 2016, p. 44.

3 On literary character of medieval texts see: M. Cetwiński, Historia i polityka. Teoria i praktyka mediewistyki na przykładzie badań dziejów Śląska, Kraków 2008, p. 213; on four meanings of the works see: D. Alighieri, Biesiada, translated and edited by M. Bartkowiak-Lerch, Kęty 2004, pp. 43-44; M. Cetwiński, Franciszkanin Pakosław, pani Klemencja i pawie, in: Katowice. W 137 rocznicę uzyskania praw miejskich, ed. A. Barciak, Katowice 2003, pp. 255-256.

4 Joannis Dlugossii Annales seu Cronicae incliti Regni Poloniae, lib. 12 (1445-1461), Cracoviae 2003, pp.110; next: Annales ....

5 M. Biskup, K. Górski, Kazimierz Jagiellończyk. Zbiór studiów o Polsce drugiej połowy XV wieku, Warszawa 1987 , pp. 316, 320, 325, 328, 335.
} 
Długosz bestowed them on many positive heroes, especially clerics ${ }^{6}$. In their portraying, he used an identical catalog of advantages and disadvantages, but differently selecting and emphasising them ${ }^{7}$. These advantages, by their very choice, reveal the historian's attitude to John of Capistrano ${ }^{8}$.

In the following part, we read that the hero of the chapter belonged to the order of brothers of smaller observers. We also learn that he was an excellent (famous, known) nobleman (genere quidem nobilis et inclitus) by origin ${ }^{9}$. Let us analyse these terms. Known, famous are the desired qualities of a positive hero. Only such a man could enjoy respect in the Middle Ages, anonymous, unknown, or strangers, because he aroused fear, triggered negative emotions and, as a consequence, the desire for isolation from society ${ }^{10}$. The noble origin also strengthened the image of the preacher ${ }^{11}$. It should be noted, however, that despite the chronicler's appreciation for the nobility, his criticism was often directed at it. Therefore, the long-term characterization of this state was often ambivalent ${ }^{12}$, hence the rest of the same sentence says that the religious was famous not because of his birth, but thanks to his actions supported by God's grace. Długosz proved again that he adhered to the providential concept of history, i.e. the belief that human fate depends on $\operatorname{God}^{13}$. John is guided by, we read further, an extraordinary love thanks to which he achieves things that are almost unattainable ${ }^{14}$. Although in the time of Długosz the love of neighbour (caritas), because this is probably the case here, unlike amor, meaning destructive and wild passion ${ }^{15}$, stood high in the hierarchy of Christian virtues, the historian attached more importance to other

\footnotetext{
6 M. Koczerska, Mentalność Jana Długosza w świetle jego twórczości, „Studia Źródłoznawcze”, 15/1971, p. 125. U. Borkowska, Regnum i sacerdotium w pismach Jana Długosza, „Studia Źródłoznawcze”, 26/1981, p. 7.

8 They indicate the author's attitude towards the specified person, see: K. Liman, Epitety dotyczace osób w kronice polskiej Anonima Galla, in: Ars historica. Prace z dziejów powszechnych i Polski, ed. M. Biskup, Poznań 1976, pp. 341-342, 344, 354-355.

9 Annales..., lib. 12 (1445-1461), Cracoviae 2003, p. 110.

10 E. Nowicka, Wprowadzenie. Inny jako obcy, in: Religia a obcość, ed. idem, Kraków 1991, pp. 11-14; M. Cetwiński, Las w polskiej legendzie heraldycznej, „Rocznik Polskiego Towarzystwa Heraldycznego”, 2/1995, j. 13, pp. 34-35; idem, Las i zamek w polskich legendach heraldycznych, in: Wokół archeologii stów i ich funkcjonowania. Księga jubileuszowa ofiarowana Profesorowi Andrzejowi Bańkowskiemu, ed. S. Podobiński, M. LeszDuk, Częstochowa 2001, p. 754; B. Kowalska, Włóczędzy, chorzy i żebracy - przykłady marginalizacji w wybranych średniowiecznych przekazach hagiograficznych, ,Tolerancja. Studia i Szkice”, 16/ 2011, passim.

11 John of Capistrano came from an Italian noble family. His father was a nobleman named Antonio, and his mother was an unknown nobleman from the de Amici family, see: W. Murawiec OFM, Jan z Kapistrano kaznodzieja podróżujący i reformator, „Studia Franciszkańskie”, 3/1988, p. 277.

12 M. Koczerska, op. cit., p. 131; K. Baczkowski, Obraz społeczeństwa polskiego w „Rocznikach i kronikach” Jana Dlugosza, „Zeszyty Długoszowskie”, 3/2004, pp. 48-49; S. Gawęda, Ocena niektórych problemów historii ojczystej w „Rocznikach” Jana Dlugosza, in: Dlugossiana. Studia historyczne w pięćsetlecie śmierci Jana Dtugosza, ed. S. Gawęda, Warszawa 1980, p. 197.

13 See: Z. Kuderowicz, Filozofia dziejów, Warszawa 1983, pp. 10-18; K. Baczkowski, Religijność Jana Dlugosza i jego fundacje kościelne, „Zeszyty Długoszowskie”, 1/2002, p. 25; J. Dąbrowski, Dawne dziejopisarstwo polskie (do roku 1480), Wrocław-Warszawa-Kraków 1964, p. 194; M. Koczerska, op. cit., p. 113. This belief is also visible among other historians, see: W. Mrozowicz, Bogu czy ludziom? O motywach twórczości dziejopisarskiej, in: Causa creandi. O pragmatyce źródła historycznego, ed. S. Rosik, P. Wiszewski, (AUWr. 2783. Historia 171), Wrocław 2005, p. 96.

14 Annales..., lib. 12 (1445-1461), Cracoviae 2003, p. 110: [...] sed operibus et gracia Divina gloriosior, ordinacione Divina, que per eximiam suam caritatem eciam invitos salvare cupit.

15 J. Le Goff, N. Truong, Historia ciała w średniowieczu, translated by I. Kania, Warszawa 2006, p. 83.
} 
qualities, e.g. to humility ${ }^{16}$. This does not change the belief that in the first sentence he built the reader's attitude to the hero.

The Krakow canon further writes that John of Capistrano left Italy, in which, for almost forty years (annis prope quadraginta), he preached the word of God and went to Moravia, where he lived in the monastery of minor brothers in Ołomun ${ }^{17}$. The approximate number cited by the author, which is indicated by the word prope, is of our interest here. Forty belongs to the favourite Długosz's catalog of numbers among which there are also 2, 3, 5, 7, 10 and $12^{18}$. This conclusion results from the insight into the whole work, because, as Umberto Eco claims: any interpretation of a fragment of a text can be accepted if it is confirmed in another fragment $^{19}$. Needless to say, the numbers listed are deeply inscribed in Christian symbolism, which cannot be missed in the passage cited above. Forty quoted in it is associated with the temporary fulfilment of a certain task, because John of Capistrano, being in Italy, consistently pursued a specific goal, consistent with accepted moral principles. Number - the symbol is not ethically indifferent ${ }^{20}$. Moses, who was waiting on Mount Sinai for forty days and nights while waiting for command boards ${ }^{21}$, was a biblical example for him. By suggesting the symbolic significance of forty, we cannot trust Dlugosz regarding the time of Capistrano's preaching activity in Italy he determined, all the more so as arithmetics does not allow it. The preacher joined the Franciscan order in 1415, and was ordained a priest and began his activity in 1417. He set out to Moravia in $1451 .{ }^{22} \mathrm{He}$ preached the word of God for 34-36 years in Italy. In general, he was active for almost 40 years wandering through European countries $^{23}$. Another source information regarding the same number confirms the mechanism shown above. Długosz reported that John of Capistrano had stayed in the monastery for 40 years ${ }^{24}$. Since he joined it in 1415 and died in $1456^{25}$ (the historian gave this date without error), which means that he was a religious for 41 years. However, it is difficult to require from the creator of a monumental work to count so precisely. Entering forty in the biography of a well-known preacher twice is still puzzling. It testifies to a message of a number other than devotion to the truth - most likely symbolic. We are again looking for confirmation of

16 See: K. Ożóg, Wpływ św. Jadwigi Królowej na chrześcijaństwo w Polsce, „Zeszyty Radomszczańskie”, 3/ 2009, pp. 7 - 8 .

17 Annales..., lib. 12 (1445-1461), Cracoviae 2003, pp. 110.

18 I am drawing this conclusion on the basis of the research into the numbers in Annales ... Jan Dlugosz, which will be published shortly.

19 U. Eco, Interpretacja i nadinterpretacja, ed. S. Collini, translation T. Bieroń, Kraków 1996, p. 64; see: S. Gawlas, Świadomość narodowa Jana Dlugosza, „Studia Źródłoznawcze”, 27/1983, p. 6.

20 A. Guriewicz, Kategorie kultury średniowiecznej, trans. J. Dancygier, Warszawa 1976, p. 300.

${ }^{21}$ Ex 24,18; see: D. Forstner, Świat symboliki chrześcijańskiej, translation W. Zakrzewska, P. Pachciarek, R. Turzyński, Warszawa 1990, p. 53.

22 M. Daniluk, John of Capistrano, in: Encyklopedia katolicka, vol. 7, ed. S. Wielgus et al., Lublin 1997, col. 796; more: EK; G. Wąs, Franciszkanie - obserwanci na Ślasku w średniowieczu. Zarys historii, in: Bernardyni na Śląsku..., p. 27.

${ }_{23}$ Fr. K. Panuś, Zarys historii kaznodziejstwa w kościele katolickim, part. 1: Kaznodziejstwo w kościele powszechnym, Kraków 1999, p. 222; M. Maciszewska, Klasztor bernardyński w społeczeństwie polskim 1453-1530, Warszawa 2001, pp. 18, 22. The author states after Jerzy Kłoczowski that Kapistran was not allowed into the Czech Republic, or Fr. Kazimierz Panuś, op. cit., p. 222; W. Murawiec OFM, op. cit., p. 287, p. 77.

${ }^{24}$ Annales..., lib. 12 (1445-1461), Cracoviae 2003, p. 269: [...] cum iam annum vite septuagesimum unum in ordine et continua diligentissimaque verbi Dei disseminacione quadragesimum exegisset.

25 M. Daniluk, op. cit., col. 796. 
this view in the work. In another place we read that the bishop of Wrocław Konrad (Konrad IV the Elder, bishop of Wrocław in the years 1417-1447), to whom Długosz assigned almost forty years of rule over the diocese ${ }^{26}$, exercised it for almost 30 years ${ }^{27}$, and another bishop of Samogitian and Vilnius, bishop Maciej, a very good bishop as the historian emphasised in the title, was to rule the diocese for over forty years ${ }^{28}$, although in reality it was a total of 36 years $^{29}$. The long-run work includes numerous examples of free treatment of the forties.

We read further that the religious continued his activities in Moravia. Because the churches did not house the faithful, the preacher addressed the people on the market, that is, as Długosz pointed out, in [...] civitatis medio ${ }^{30}$. An average recipient of the work did not have to be made aware of the location of the market in the city ${ }^{31}$. Therefore, Długosz did it deliberately, pointing to the prestigious place of the activity of the preacher ${ }^{32}$. As for medieval artists it was crucial that important events took place in the center, and in the opinion of the author as those with the participation of John. It was not so much about order and security connected with the center of space $^{33}$, but about the possibility of better contact with God, after all, it was easier to reach the heavenly forces from the center ${ }^{34}$. There is no doubt that the events concerned divine matters. The preacher preached Verbum Dei, and the divine element is vividly present throughout the story. Długosz added that the words transmitted by Kapistran were translated into German and $\mathrm{Czech}^{35}$. This mission was entrusted to one of the Franciscan brothers from Moravia. Stanisław from Kobylin translated sermons into Polish ${ }^{36}$. The preachers of

\footnotetext{
${ }^{26}$ Annales..., lib. 12 (1445-1461), Cracoviae 2003, p. 50: Hic pontifex erat dux Slesie de Oleschnicza et annis prope quadraginta rexit illam ecclesiam.

27 See: R. Heck, Konrad IV Starszy, biskup wrocławski (1417-1447), in: Polski słownik biograficzny, vol. 13, ed. B. Leśnodorski, Wrocław 1991, col. 590-591.

28 Annales..., lib. 12 (1445-1461), Cracoviae 2003, p. 154: Qui primum Samagitie, deinde Vilnensis episcopus ultra quadraginta annos in pontificatu exegerat.

29 S. Brzozecki, Maciej, Maciej z Wilna, Maciej z Trok, in: EK, vol. 11, ed. S. Wilk, Lublin 2006, col. 705-706; Jan Długosz, Roczniki czyli kroniki sławnego Królestwa Polskiego, book 12 (1445-1461), translation J. Mrukówna, Warszawa 2004, p. 173, footnote 20; Maciej (Mathias), in: Wileński słownik biograficzny, ed. H. Dubowik, L.J. Malinowski, Bydgoszcz 2002, p. 212.

30 Annales..., lib. 12 (1445-1461), Cracoviae 2003, p. 111.

31 About the market in the topography of a medieval town see: H. Samsonowicz, Życie miasta średniowiecznego, Warszawa 2001, p. 49; M. Bogucka, H. Samsonowicz, Dzieje miast i mieszczaństwa w Polsce przedrozbiorowej, Wrocław-Warszawa-Kraków, Łódź 1986, pp. 96-97.

32 B. Geremek, O Średniowieczu, preface and selection H. Zaremska, ed. H. Zaremska, A. Niegowska, Warszawa 2012, p. 609: Rynek byt miejscem prestiżowym....

33 B. Geremek, Człowiek marginesu, in: Człowiek średniowiecza, ed. idem, translation M. Radożycka-Paoletti, Warszawa 2000, p. 439.

34 See: M. Eliade, Sacrum, mit, historia, preface and selection M. Czerwiński, trans. A. Tatarkiewicz, Warszawa 1993, p. 53 and next; J. Wiesiołowski, Ziemia święta w rzeczywistości i legendzie średniowiecza, in: Ziemia święta w rzeczywistości i legendzie średniowiecza. Materiały XVI Seminarium Mediewistycznego, ed. idem in coop. J. Kowalski, Poznań 1996, p. 7.

${ }_{35}$ Annales..., lib. 12 (1445-1461), Cracoviae 2003, p. 111: verbum Dei diligentissime per duos interpretes, unum Bohemum alterum Almanum predicabat; see: A. Lissowska, op. cit., p. 59.

36 A. Zajchowska, op. cit., p. 55; G. Maroń, Święci patroni prawników, Rzeszów 2011, p. 150.
} 
that period made sure that the words they preached were understood by the local people ${ }^{37}$. The canon from Kraków repeated this at every opportunity ${ }^{38}$.

From the very beginning, Długosz created John as a positive hero, which he expressed by assigning him more, this time superhuman, abilities. He said that the preacher did miracles (Predicaciones autem suas signis et operibus stupendis confirmabat), above all he resurrected and healed. He also had the gift of prophecy (spiritu eciam pollens prophetico ${ }^{39}$. Thanks to these deeds, he gained incredible influence, and many inhabitants of Bohemia and Moravia were to leave Hussitism and convert to pure Catholic faith ${ }^{40}$. Miracle-making and prophecy are gifts from God to extraordinary people, especially saints ${ }^{41}$, who thanks to them were to strengthen Christian faith and arouse admiration of the people surrounding them ${ }^{42}$. In a broader context, miraculous events were to include people's history in sacred history ${ }^{43}$, the existence of which the historian emphasised many times. Although John of Capistrano was not a saint yet, because his canonisation took place in $1690^{44}$, Długosz saw him as such. The chronicler spared no effort to bring saints to the $\operatorname{church}^{45}$. Thus, he convinced the recipients of the work via different means, most likely in line with their expectations, of the holiness of Capistran. Medieval people gladly saw saints in their non-canonised heroes. Respected by the chronicler, enjoying his interest, an outstanding preacher known throughout Europe ${ }^{46}$; he was perfect for such a role.

Great people in the persons of Cardinal Zbigniew Oleśnicki and King Casimir IV Jagiellon invited John of Capistrano to Poland, as Długosz confirmed it ${ }^{47}$ by quoting Oleśnicki’s letter

37 That is why it was preached in a native language, see: I. Skierska, Obowiazek mszalny w średniowiecznej Polsce, Warszawa 2003, p. 182 and the followiung; J. Dowiat, Środki przekazywania myśli, in: Kultura Polski średniowiecznej X-XIII w., ed. idem, Warszawa 1985, p. 200-201; Fr. K. Panuś, op. cit., p. 222; M. Maciszewska, Klasztor bernardyński..., p. 18.

38 B. Kowalska, Długoszowe pojmowanie wojny sprawiedliwej, in: Kościół i społeczeństwo. Studia nad obiegiem informacji i konfliktami zbrojnymi w dawnych wiekach, ed. J. Grabowski, Warszawa 2012, p. 184; further: Kościót i spoleczeństwo... .

39 Annales..., lib. 12 (1445-1461), Cracoviae 2003, p. 111.

40 M. Daniluk, op. cit., col. 796.

41 B. Geremek, O Średniowieczu, p. 425.

42 On the function of miracles see: A. Kuźmiak-Ciekanowska, Święty $i$ historia. Dynastia Przemyślidów $i$ jej bohaterowie $w$ dziele mnicha Krystiana, Kraków 2007, p. 157; A. Witkowska, Miracula średniowieczne - funkcje przekazu ustnego i zapisu literackiego, in: Kultura elitarna a kultura masowa w Polsce późnego średniowiecza, ed. B. Geremek, Wrocław-Warszawa, Kraków-Gdańsk, pp. 184, 186; A. Kowalska-Pietrzak, W cieniu świętości, czyli o zwyczajnej kobiecie w państwie Piastów, in: Per mulierem ... Kobieta w dawnej Polsce $-w$ średniowieczu $i$ w dobie staropolskiej, ed. K. Justyniarska-Chojak, S. Konarska-Zimnicka, Warszawa 2012, p. 32.

43 See: J. Zagożdżon, Sen w literaturze średniowiecznej i renesansowej, Opole 2002, p. 183.

44 M. Daniluk, op. cit., col. 797.

45 S. Gawlas, op. cit., p. 4.

46 Rozbiór krytyczny Annalium Poloniae Jana Dlugosza z lat 1445-1480, vol. 2, ed. S. Gawęda, K. Pieradzka, J. Radziszewska, under supervision of J. Dąbrowski, Wrocław, Warszawa, Kraków 1965, p. 37; further: Rozbiór krytyczny... .

47 Annales..., lib. 12 (1445-1461), Cracoviae 2003, p. 111: ,Huic viro Ioanni de Capistrano tam claro et insigni Sbigneus cardinalis Cracoviensis, volens humanitatis exhibere officium, sibi literas scribit rogando, ut si a Bohemis contemptus fuerit, in Poloniam descendat. Idem facit Casimirus rex; see: M. Maciszewska, Klasztor bernardyński..., p. 19; idem, Bernardyni a władze lokalne w Królestwie Polskim w XV i XVI wieku, in: Klasztor w państwie średniowiecznym i nowożytnym, ed. M. Derwich, A. Pobóg-Lenartowicz, Wrocław- Opole-Warszawa 2005, p. 492; Fr. H.E. Wyczawski OFM, Kraków, in: Klasztory bernardyńskie w Polsce w jej granicach historycznych, ed. idem, Kalwaria Zebrzydowska 1985, p. 154; further: Klasztory bernardyńskie... . 
to the preacher from August 2, 1451, which is known only from the text contained in the Annals... ${ }^{48}$ This letter, perhaps rewritten, most likely in extenso, was a source of knowledge about the past for Długosz, but also a propaganda tool that helped him shape appropriate beliefs and attitudes for recipients ${ }^{49}$. Therefore, it was related to the topic discussed in the previous chapter, and the full text quoted was to enable accurate knowledge of the whole case $^{50}$, which was announced by the word $\operatorname{cognoscere} e^{51}$, often used in such cases. The letter contained arguments which were used by Długosz himself in his work to confirm the truth, as if it had been handwritten. We know well that this agreement of thoughts resulted from the closeness of views of the Cardinal and his mentee ${ }^{52}$. So here we are talking about secret divine judgments, holy faith and its opponent, devil. In the letter, John was called a man of prudence and a scholar (vir prudens et doctus), a pilgrim who went to strangers (extera regna vel pocius barbara adisti) $)^{53}$. The preacher's listed virtues and undertakings further strengthened his authority. Attributing one of the four cardinal virtues - prudence (prudentia) $^{54}$ - is another step in the process of idealising the hero. Wisdom was also a valuable feature, although education and knowledge do not take up much space in the portraits of Długosz's heroes. It seems that the historian valued moral rather than intellectual values more ${ }^{55}$. This time, however, the latter was noticed, because the dignity of the preacher was highly valued in the Middle Ages and was entrusted to especially gifted people ${ }^{56}$. Perhaps in this case Długosz was guided by a classic medieval example - the biblical Salomon as rex sapiens $^{57}$.The pilgrimage assigned to Kapistran also had a positive tone in the Middle Ages. It was associated with wandering in search of $\mathrm{God}^{58}$. The topos of the pilgrim is, moreover, vividly present in all the literature of this period ${ }^{59}$.

When we move to the events of 1453 , our attention is drawn to the chapter entitled John of Capistrano from the Order of Friars Minor - observers of Saint Bernardine - is

48 Rozbiór krytyczny..., p. 38.

49 A. Nalewajek, Funkcje dokumentów w Rocznikach Jana Dlugosza, in: Piśmiennictwo Czech i Polski w średniowieczu i we wczesnej epoce nowożytnej, ed. A. Barciak, W. Iwańczak, Katowice 2006, p. 36, 42.

${ }^{50}$ Annales..., lib. 12 (1445-1461), Cracoviae 2003, p. 111: que ut lacius cognosci possint, literas ipsas et earum tenorem inserui.

51 See: A. Nalewajek, op. cit., p. 39.

52 On close relations between Długosz and Bishop Oleśnicki: J. Nikodem, Zbigniew Oleśnicki w historiografii polskiej, Kraków 2001, pp. 15-57.

53 Annales..., lib. 12 (1445-1461), Cracoviae 2003, pp. 112-113.

${ }^{54}$ K. Ożóg, op. cit., p. 7.

55 See: J. Krzyżaniakowa, „Eruditio” et „,scientia” w Dlugoszowych wizerunkach władców i biskupów, in: Mente et litteris. O kulturze i społeczeństwie wieków średnich, ed. H. Chłopocka, J. Krzyżaniakowa, G. Labuda, Poznań 1984, pp. 278-279.

56 See: ks. W. Pazera, Kaznodziejstwo w Polsce od początku do końca epoki baroku, Częstochowa 1999, p. 100.

57 Ibidem.

58 D.A. Kulasówna, Kult i legenda o Kindze, in: Z dziejów średniowiecznej Europy środkowowschodniej. Zbiór studiów, ed. J. Tyszkiewicz, Warszawa 1998, pp. 66-67; about different purposes for undertaking pilgrim's journey see: J. Wiesiołowski, op. cit., p. 8 and next.; A. Gieysztor, Między hagiografia a biografia mediewistyczną: święty Wojciech, in: Stan i perspektywy rozwoju biografistyki polskiej, ed. L. Kuberski, Opole 1998, p. 54.

59 T. Michałowska, Topika pielgrzyma i pielgrzymki w literaturze polskiego średniowiecza, in: Peregrinationes. Pielgrzymki w kulturze dawnej Europy, ed. H. Manikowska, H. Zaremska, Warszawa 1995, pp. 72-85; idem, Topika pielgrzymia w literaturze polskiego średniowiecza, in: eiusdem, Mediaevalia i inne, Warszawa 1998, pp. 26-44; B. Kowalska, Bitt-, Dank- und Bußpilgerfahrten in den „Annnales seu Cronicae incliti Regni Poloniae” von Jan Dlugosz (1415-1480), „Bulletin der Polnischen Historischen Mission”, 10/2015, passim. 
received in Krakow to the great joy of all the orders, he preaches there and liftens up the spirit of the sick (original: John of Capistrano z zakonu minorytów - obserwantów świętego Bernardyna - zostaje podjęty w Krakowie ku wielkiej radości wszystkich zakonów, głosi tam kazania i pokrzepia chorych) ${ }^{60}$. Długosz, a direct witness to the events ${ }^{61}$, said that the noble newcomer was greeted by a large retinue: the king and his mother Zofia, the bishop of Oleśnickie, orders, the entire clergy and municipal authorities ${ }^{62}$. This order of particular representations indicates the priority that the historian gave to states in creating important events. The clergy, as you can see, plays a privileged role here ${ }^{63}$. We read further that the preacher entering the city was accompanied by processions and banners (processionibus sacris et vexillis) ${ }^{64}$. The processions were a momentous, extremely colourful and dynamic moment of religious and aesthetic experiences of people of the late Middle Ages ${ }^{65}$. They emphasised the solemn nature of not only religious but also state events. It is difficult to say whether the city or church banners were present in this procession ${ }^{66}$. Organising the procession when the great preacher enters the city is therefore not surprising. The next source information is also not surprising at first glance. We read that John of Capistrano was welcomed by 2000 (duo milliaria) townspeople ${ }^{67}$. An insight into the entire work of Długosz gives grounds to conclude that the historian used full, large numbers very willingly, especially when they were to serve a purpose. In this case, the number strengthens the belief that immortal things are happening, because, according to Długosz, 2000 inhabitants of Krakow are almost the entire city (fere universa civitate). To emphasise the magnificence of the person or the importance of the event, the canon of Krakow used terms such as prope, fere, meaning approximate data, which is often difficult to verify. However, since it is estimated that Ladislaus' Cracow already had about 10 thousand inhabitants ${ }^{68}$, then the Długosz's Cracow had to have more ${ }^{69}$. Therefore, the number does not serve to convey historical truth, but to strengthen the belief that the arriving person is extremely important, because it welcomes almost the entire city. The elevated mood of this event was also given by Długosz in the Liber beneficiorum dioecesis Cracoviensis $^{70}$. However, they neither contained the information about the crimson-covered

\footnotetext{
${ }^{60}$ Annales..., lib. 12 (1445-1461), Cracoviae 2003, p. 171: Ioannes Capistranus ordinis Minorum de observantia sancti Bernardini summa omnium ordinum laetitia Cracoviae excipitur, contionatur ibidem et curat infirmos.

${ }_{61}$ See: M. Maciszewska, Klasztor bernardyński..., p. 20; M. Koczerska, op. cit., p. 111, about the Długosz's attitude to the events observed by him.

62 Annales..., lib. 12 (1445-1461), Cracoviae 2003, p. 171.

${ }_{63}$ See: U. Borkowska, Treści ideowe w dziełach Jana Dlugosza. Kościót i świat poza Kościołem, Lublin 1983, p. 198; K. Baczkowski, Obraz spoteczeństwa polskiego..., p. 45; M. Koczerska, op. cit., p. 131; S. Gawęda, op. cit., p. 199.

${ }^{64}$ Annales ..., lib. 12 (1445-1461), Cracoviae 2003, pp. 171.

${ }^{65}$ U. Borkowska, Przykład pobożności mieszczańskiej w XV wieku. Weronika z Krakowa, in: Sztuka i ideologia XV wieku. Materiały sympozjum Komitetu Nauk o Sztuce Polskiej Akademii Nauk, Warszawa Dec 1-4 1976, ed. P. Skubiszewski, Warszawa 1978, p. 115; B. Geremek, O średniowieczu, p. 606.

${ }_{66}$ See: J. Ptak, Choragiew w komunikacji społecznej w Polsce piastowskiej i jagiellońskiej, Lublin 2002, p. 110.

67 Annales..., lib. 12 (1445-1461), Cracoviae 2003, p. 171.

68 H. Samsonowicz, Polska w gospodarce europejskiej XIV i XV wieku, in: Polska dzielnicowa i zjednoczona. Państwo, społeczeństwo, kultura, ed. A. Gieysztor, Warszawa 1972, p. 371.

${ }_{69}$ Grzegorz Maron writes that the number of Cracow's dwellers during this period was about 15 thousand people see: G. Maroń, op. cit., p. 150, footnote 290.

70 Joannis Dlugossii, Liber beneficiorum dioecesis Cracoviensis, vol. 3, Cracoviae 1864, p. 478; W. Murawiec OFM, op. cit., p. 290.
} 
stairs leading to the place of the ceremony ${ }^{71}$ in this text nor in Historia Polonicae, as we read in the literature of the subject. There is, however, a comparison of the Krakow procession to the procession of the Romans greeting the victorious Scipio after a successful expedition to Africa $^{72}$. Długosz exaggeratedly stated that the guest saw greatness in Krakow not found in other places ${ }^{73}$. Considering the countries the preacher visited, the statement was too bold. It was not meant to serve historical truth, but to emphasise the importance of the place to which the historian showed great attachment.

We can still see given the medieval writers' penchant for full numbers in several places the account of the great preacher's stay in Krakow. The chronicler argues that under the influence of Capistran's miracles, over a hundred people joined the Franciscan Order of Observants in this city ${ }^{74}$. In the files of the canonisation process a specific number is given $-130^{75}$. Obviously, Długosz did not know these files, because they were created later, in principle, he did not lie to the reader, because he said that the case concerns more than a hundred people. The same number, i.e. 100, was given by Jan of Komorów, who lived in the years 1470-1536, a chronicler and provincial of Bernardines ${ }^{76}$. This information, however, does not add anything to our considerations regarding the sources of knowledge of the Krakow canon, because of the time later than Dugoszów's activity of Jan of Komorów. It is important, however, that a contemporary to our historian, because created in the time of Casimir IV Jagiellon, Lviv Souvenirs give the number seventy ${ }^{77}$. Should there be any manipulation in the writing practices of the Krakow canon writer who, perhaps, was the first to give the number one hundred? In this case, it is again necessary to refer to the entire work, in order to be able to conclude that Długosz used numbers in a chosen manner, and this one as ten times ten, the ideal number, both in the Pythagorean system and in Christian symbolism, was highly valued ${ }^{78}$. It is possible that the Krakow canon writer, eagerly rewritten by later

71 A.E. Obruśnik OFM, Św. John of Capistrano kaznodzieja i reformator. Wybrane zagadnienia z ikonografii bernardynów w Polsce, „Studia Franciszkańskie”, 5/1992, pp. 303-304, where there is an interpretation of this fragment; cf.. Joannis Dlugossii, Liber beneficiorum..., p. 478; idem, Historiae Polonicae libri XII, ed. J. Żegota, A. Przezdziecki, vol. 5, Cracoviae 1878, p. 148.

72 Joannis Dlugossii, Liber beneficiorum ..., p. 478; see: W. Murawiec OFM, op. cit., p. 290; A.E. Obruśnik OFM, op. cit., 303-304.

73 W. Murawiec OFM, op. cit., p. 290.

74 Annales..., lib. 12 (1445-1461), Cracoviae 2003, p. 171: ,Centum et amplius persone sacram religionem suam ingresse sunt.

75 K. Kantak, Bernardyni polscy, t. 1: 1453-1572, Lwów 1933, p. 10; M. Maciszewska, Klasztor bernardyński..., p. 22; J. Wolny, Kaznodziejstwo, in: Dzieje teologii katolickiej w Polsce, vol. 1: Średniowiecze, ed. M. Rechowicz, Lublin 1974, p. 330; W. Murawiec OFM, op. cit., p. 291; cf. Fr. K. Panuś, op. cit., p. 222, where 4000 observers were enlisted in total.

76 Memoriale ordinis Fratrum Minorum a fr. Ioanne de Komorowo compilatum, wyd. X. Liske et A. Lorkiewicz, in: Monumenta Poloniae Historica, vol. 5, Warszawa 1961, p. 169: Sub eo centum persone at amplius sacram religionem sancti Francisci de Observancia assumpserunt; see: M. Maciszewska, Klasztor bernardyński..., p. 22; Z. Spieralski, Jan z Komorowa h. Korczak (ok. 1470-1536), in: Polski słownik biograficzny, vol. 10, ed. K. Lepszy, Wrocław, Warszawa, Kraków 1962-1964, p. 457; Fr. H.E. Wyczawski OFM, Wstęp, in: Klasztory bernardyńskie..., p. 14; o. A. Chadam OFM, Poznań, in: Klasztory bernardyńskie ..., p. 268; o. K. Grudziński OFM, Warta, in: Klasztory bernardyńskie..., p. 421, 423. About the editions of the chronicles of Jan of Komorow see: S. Bylina Mesjasz z Gór Świętokrzyskich, „Odrodzenie i Reformacja w Polsce”, 33/1988, p. 5 footnote 1.

77 Spominki lwowskie, ed. A. Bielowski, in: Monumenta Poloniae Historica, vol. 3, Lwów 1878, p. 251; see: M. Maciszewska, Klasztor bernardyński..., p. 22.

78 See: M.C. Ghyka, Złota liczba. Rytuaty i rytmy pitagorejskie w rozwoju cywilizacji zachodniej, trans. I. Kania, Kraków 2001, pp. 33-36; M. Cetwiński, Kadtubek i Pitagoras. Recepcja filozofii Zachodu w polskich kronikach 
authors, shaped the tradition of the number of novices of the Krakow Convention, which functioned in this form for the next centuries, for example for the mentioned Jan of Komorów.

In a tone clearly indicating the emotional involvement of Johannes Longinus in the described events, further narrative is maintained. The chronicler argues that John of Capistrano (quolibet die) celebrated masses everyday, and, as in Moravia, he did so in the market, in the center ${ }^{79}$. This information cannot be verified, because in contrast to Wroclaw sermons, Krakow ones did not survive ${ }^{80}$. The cited mention is not particularly surprising, because the main task and duty of every priest resulting from the ordination of priesthood was and is to celebrate the Eucharistic Sacrifice ${ }^{81}$. However, the medieval norms of the Western Church did not require priests to celebrate mass every day, hence priests rarely did $\mathrm{it}^{82}$. Because it was only recommended by the Second Vatican Council ${ }^{83}$, zeal in fulfilling this duty in the time of Długosz deserved to be emphasised. Writing about the daily celebration of mass by John of Capistrano, the historian convinces the reader that the preacher's contact with God was extremely strong, because the Mass is, after all, a special meeting with sacrum $^{84}$. Długosz also assured that only great people would experience such grace, and above all who were prudent and wise, once again attributing important virtues to the hero.

Not yet saint, but treated as such John of Capistrano received further qualities from the Krakow canon. We read, therefore, that the preacher used reason and celestial language (lingua celesti) ${ }^{85}$. Caelestinus, celestinus, coelestinus in the Middle Ages means both heavenly and celestial ${ }^{86}$. Celestis, $-e$ (from caelum) is heavenly, located or taking place in heaven, coming from heaven ${ }^{87}$. This interpretation had already been proposed by Saint Augustine in Confessions in which the blue colour is clearly assigned to heaven ${ }^{88}$. Capistrano's language and reason, the tools he especially needs to perform the function of a preacher, are therefore firmly connected with heaven, or God's seat, and consequently with God himself. On the topics of the heavenly chambers, with blue rays shining over the chopped body of St. Stanislaus and the heavenly lights radiating from this body and the heavenly power of Saint Dominic, Długosz writes in other fragments of the work ${ }^{89}$. There are many examples of this type, especially in

średniowiecznych, in: Tradycje duchowe Europy Środkowej i Wschodniej, ed. S. Chazbijewicz, J. Kwapiszewski, Słupsk 1999, pp. 120, 127; J. Legowicz, Zarys historii filozofii. Elementy doksografii, Warszawa 1980, p. 53.

79 Annales..., lib. 12 (1445-1461), Cracoviae 2003, p. 171; see: J. Wolny, op. cit., p. 298; ks. K. Panuś, op. cit., p. 222; M. Daniluk, op. cit., col. 797; W. Murawiec OFM, op. cit., p. 290; A. Zajchowska, op. cit., p. 44.

80 W. Murawiec OFM, op. cit., p. 281.

81 E. Szczot, Msza III. W prawie kanonicznym, in: Encyklopedia katolicka, vol. 13, ed. E. Gigilewicz, Lublin 2009, col. 447.

82 I. Skierska, op. cit., p. 108, 110.

83 Ibidem.

${ }^{84}$ M. Saczyńska, Msza pod ostona nieba, czyli kiedy kultura spotyka się z naturą. Sprawowanie eucharystii w czasie podróży w okresie średniowiecza - uwagi wstępne, in: Mundus hominis - cywilizacja, kultura, natura, ed. S. Rosik, P. Wiszewski, Wrocław 2006, p. 255.

85 Annales..., lib. 12 (1445-1461), Cracoviae 2003, p. 171.

86 See: Stownik łaciny średniowiecznej w Polsce, ed. M. Plezia, vol. 2, bulletin 1(9), Wrocław-Kraków-Warszawa 1959-1967, p. 15.

87 Stownik łacińsko-polski, ed. M. Plezia, vol. 1, Warszawa 1959, p. 395.

88 St. Augistin Wyznania, translation, afterword and chronology Z. Kubiak, Warszawa 1987, pp. 374-375.

89 Annales..., lib. 1, 2, Varsaviae 1964, p. 164; ibidem, lib. 3, 4, Varsaviae 1970, pp. 137, 139; ibidem, lib. 5, 6, Varsaviae 1973, p. 229. 
the stories of saints. For to them, as the inhabitants of heaven, as well as to the future saint, John Capistrano, the term heaven - heavenly suited specifically.

In Długosz's accounts on the preacher, one also wonders when Saint Augustine is recalled twice. The historian does it for the first time, telling about the arrival of John of Capistrano to Krakow, which was to take place in die sancti Augustini ${ }^{90}$ - August 28, 1453 ${ }^{91}$, and which was repeated several lines below ${ }^{92}$. Since the Wrocław chronicler Piotr Eschenloer ${ }^{93}$ determined that the preacher's stay in Wroclaw was until August $31^{94}$, one can ask the question whether the date of Capistrano's arrival in Krakow at Długosz's is too early ${ }^{95}$. Is it therefore incorrect or even intentional $?^{96}$ The Krakow canon eagerly registered great events on the days of the saints of the Catholic Church. This was due to medieval dating techniques, but also to the belief that the watchful eye of the saint would contribute to the successful course of events ${ }^{97}$. An example of such thinking is the presentation of the bishop of Wrocław, Przecław of Pogorzela, in the text De institucione ecclesie Wratislaviensis attached to the Chronicles of Polish Dukes (original title: Kronika ksiażat polskich), in which the most important moments of the hierarch's life are inscribed on St. Gothard's day, though this is not always true ${ }^{98}$. Stefan Krakowski caught Długosz manipulating dates in stories about the saint patrons. According to the historian, the chronicler mistakenly built the chronology of the Jadwiga arrival to Poland in 1282, assuming that St. Archangel Michael intervenes only on his own days and thus forgetting that as a patron of knights he intervenes in the fight regardless

90 Annales..., lib. 12 (1445-1461), Cracoviae 2003, . 171; alike Jan of Komorow, Memoriale ordinis..., pp. 168-169 .

9128 VIII to dies natalis św. Augustyna; see: A. Pobóg-Lenartowicz, Kult świętych w śląskich klasztorach kanoników regularnych, in: Ecclesia et civitas. Kościół i życie religijne w mieście średniowiecznym, ed. H. Manikowska, H. Zaremska, Warszawa 2002, p. 443. Jan Kapistran was in Krakow from Aug 281453 to May 141454 r., see: M. Maciszewska, Bernardyni a władze lokalne..., p. 489; G. Maroń, op. cit., p. 149. We read about eight months in Kalendarz krakowski; see: Calendarii Cracoviensis, ed. W. Bruchnalski, in: Monumenta Poloniae Historica, vol. VI, Kraków 1893, pp. 673-674: intrat Cracoviam, ubi octo mensibus prope quolibet die predicavit.

92 Annales..., lib. 12 (1445-1461), Cracoviae 2003, p. 172: Mansit autem in civitate Cracoviensi a die sancti Augustini.

93 On the activity and literary output of Piotr Eschenloer see: W. Iwańczak, Piotr Eschenloer-świadek epoki, in: Tysiacletnie dziedzictwo kulturowe diecezji wrocławskiej, trans. Barciak, Katowice 2000, pp. 160-170, especially ibid. 161-163, 170, opinions about Eschenloer's writing.

94 Piotr Eschenloer, however, did not witness the events. He came to Wrocław in 1455, so two years after the arrival of John of Capistrano to Poland, the chronicle was created in the sixties and at the beginning of the seventies of the fifteenth century, see: W. Mrozowicz, Dziejopisarstwo średniowieczne we Wrocławiu, „Sobótka”, 61/2006, bulletin 1., pp. 16-17. About Capistrano's arrival to Wrocław see: Kroniki Bernardynów poznańskich, ed. S.B. Tomczak OFM, J. Wiesiołowski, Poznań 2002, p. 29; J. Drabina, Życie codzienne w miastach ślaskich XIV i XV wieku, Opole 1991, p. 126. About preacher's stay in Wrocław see: G. Maroń, op. cit., pp. 146-149; about his stay in Cracow see: ibidem, pp. 149-153.

95 Rozbiór krytyczny..., p. 59.

96 Historians insist that John of Capistrano stayed in Wroclaw almost until the end of August, see: W. Murawiec OFM, op. cit., p. 288.

97 See: A. Barciak, Uwagi o konstrukcjach czasowych narracji historycznej Galla Anonima $i$ Kosmasa, in: Piśmiennictwo Czech i Polski w średniowieczu i we wczesnej epoce nowożytnej, ed. A. Barciak, W. Iwańczak, Katowice 2006, p. 71; M. Plezia, Wstęp, in: Anonim tzw. Gall, Kronika polska, translated by R. Grodecki, ed., introduction and footnotes M. Plezia, Wroclaw-Warsaw-Krakow 1996, p. IX-X, about the protective role of St. Idzi towards Bolesław Krzywousty.

98 See: M. Cetwiński, ,,In die sancti Gothardi”; „Kronika książąt polskich” o biskupie Przecławie, in: Kościót i społeczeństwo..., pp. 43-49. 
of the day of his feast ${ }^{99}$. Attaching special importance to the protective role of the saints, Długosz emphasised St. Augustine's day qualitatively flawlessly ${ }^{100}$ as the time of the hero's arrival to Krakow. This does not mean, however, that this time he was free to use historical data and postponed the date of Capistrano's arrival in Poland. As an event participant, he could not rather allow it. He allowed himself to emphasise the belief that St. Augustine was a great guardian of the great preacher. He did it elsewhere in the work by comparing two great characters. We read, therefore, that Capistrano, devoted to matters of faith, quod velut alter beatissimus Augustinus (like the second Saint Augustine) calmly gave his spirit to the Lord $^{101}$. The source closeness of the saint and the future saint also, and perhaps especially at the time of death, results from the conviction of medieval creators about the connectivity and mutual assistance of beings who are closest to God and constituting a communio sanctorum. It is also an expression of the eschatological understanding of holiness as a community of all saints, regardless of official recognition by the Church $^{102}$. Comparison of Capistrano to Saint Augustine perhaps also had its basis in the biographical similarities of the great figures of the Church, among which conversion and life turns were the most important ${ }^{103}$. On the other hand, clear connection is evident in the ideas of both saints, especially the fundamental ones - the idea of the unity of humanity, in Capistrano's Europe, leading to the unity of the Church, based on the vision of Augustine about the ideal state of God, harmoniously governed by the spiritual power of the pope and the secular emperor ${ }^{104}$. Dlugosz's admiration for the Augustinian concept of time and divine rule over $\mathrm{it}^{105}$ reinforces the supposition of the deliberate recall of the Bishop of Hippo in accounts of the European preacher.

Therefore, Długosz sees in his hero a man particularly associated with God and his servants, saints, we are convinced of it by the next chapter about the fight of the Turks with Christian rulers for Belgrade in $1456^{106}$. The report contains a number of factual errors and it is difficult to precisely determine the sources from which Długosz drew information, but this is not what interests us here ${ }^{107}$. Let us look at how the chronicler presented the hero of the events. John of Capistrano, a venerable husband of extraordinary sanctity (venerandus pater Iohannes Capistranus, vir singularis sanctitatis) and again this time he became in his

\footnotetext{
99 See: S. Krakowski, Obrona pogranicza wschodniego Małopolski za Leszka Czarnego, „Zeszyty Naukowe UŁ. Nauki Humanistyczno-Społeczne", series 1, 15/1960, p. 106.

100 See: B. Geremek, Wyobraźnia czasowa polskiego dziejopisarstwa średniowiecznego, „Studia Źródłoznawcze”, 22/1977, p. 9.

101 Annales ..., lib. 12 (1445-1461), Cracoviae 2003, pp. 269.

102 See: M. Michalski, Kobiety i świętość w żywotach trzynastowiecznych księżnych polskich, Poznań 2004, pp. 290-291.

103 See: W. Murawiec OFM, op. cit., p. 278.

104 Ibidem, p. 274; cf. Z. Kuderowicz, op. cit., p. 10-18. O idei „Christianitas” see: Fr. M.T. Zahajkiewicz, Integracyjna rola Kościoła $w$ Polsce średniowiecznej, in: Pamiętnik XV powszechnego zjazdu historyków polskich, vol. 1 part 1, ed. J. Staszewski, Gdańsk, Toruń 1995, pp. 186-187.

105 Annales ..., lib. 12 (1445-1461), Cracoviae 2003, p. 112; about theses concepts see: Z. Kuderowicz, op. cit., pp. 10-18.

106 Annales ..., lib. 12 (1445-1461), Cracoviae 2003, p. 253.

107 The mention of the Belgrade mission Capistran is also contained in the Żagan chronicle of regular canons, see: Catalogus abbatum Saganensium, ed. G.A. Stenzel, in: Scriptores Rerum Silesiacarum, Bd. I, Breslau 1835, pp. 332-334.Interpretation of this text fragment see: K. Chmielewska, Ślascy kanonicy regularni wobec konfliktów zbrojnych. Wojsko i wojna w średniowiecznych kronikach klasztornych, in: Kościół i społeczeństwo..., p. 203.
} 
eyes a spokesman for the divine will, because he encouraged to participate in the war ${ }^{108}$, a just war $^{109}$, which was not emphasised without a reason. Justice comes from God $^{110}$, and all those, who realise it, are faithful followers. Therefore, the preacher, with his pleas and tears, argued for the necessity of fighting, becoming the spiritual guardian of the whole undertaking ${ }^{111}$. The clergy could participate in this just war only by giving encouragement, only in this way. Tears that will appear again, just before Capistrano's death and that will be his tears again, heighten the mood - express humility and reconciliation with fate - especially at the time of dying. During the fight, however, they are an expression of a plea for help in subjugating infidels. The source of this attitude is again the biblical reality in which many heroes shed tears, begging for their own or someone else's cause ${ }^{112}$. In the Middle Ages, tears were a gift, they became a sign of imitation of Christ, and from the eleventh century they were even a criterion of holiness ${ }^{113}$. In the Bernardine sermons of the passion type, which the hero repeatedly preached, crying occurred with particular frequency with all related words. For they expressed a positive religious attitude ${ }^{114}$. Therefore, it is not surprising that the gift of tears was entered twice in the source biography of John of Capistrano.

The clash with the overwhelming Turks was extremely fierce - continues Długosz. John of Capistrano encouraged dubious Christians to fight, explaining that victory does not depend on the size of the army, but on the attitude of Christ's knights. Their trust and faith in God's help will ensure victory from heaven (victoria de caelo) ${ }^{115}$. The word Jesus spoken by the knights, was supposed to be a battle cry slogging opponents. It was no coincidence that it accompanied Capistrano's deeds, after all, the cult of the name Jesus became a constant element of Bernardine piety, hence they were often called during sermons as a break to intensify the dramaturgy of the event ${ }^{116}$. The preacher was a great proponent of this cult $\mathrm{t}^{117}$. Along with Bernardine of Siena, he was even accused of idolatry calling for the name Jesus, but he managed to defend his case against the papal commission ${ }^{118}$. Number three composed into the narrative several times (infra triduum - in three days, trini - three times, tercia

\footnotetext{
${ }^{108}$ Annales..., lib. 12 (1445-1461), Cracoviae 2003, p. 254. On John of Capistrano's participation in ani-turkish crusade see: Fr. K. Panuś, op. cit., p. 183, 224; M. Cetwiński, Idee dziejopisarstwa wrocławskiego na progu czasów nowożytnych, in: eiusdem, Metamorfozy śląskie. Studia źródłoznawcze i historiograficzne, Częstochowa 2002, p. 196; M. Maciszewska, Klasztor bernardyński..., p. 23 (ibid works cited); M. Daniluk, op. cit., col. 797.

109 About a just war see: Ph. Contamine, Wojna $w$ średniowieczu, trans. M. Czajka, Warszawa 1999, p. 291 and next; B. Kowalska, Dtugoszowe pojmowanie wojny..., pp. 183-194.

110 See: Z. Ziembiński, O pojmowaniu sprawiedliwości, Lublin 1992, p. 22; M. Koczerska, op. cit., pp. 136-138; L. Łbik, Pamięć podszyta tęsknotą. Król Kazimierz Wielki w legendach i podaniach ludowych, in: Kazimierz Wielki i jego państwo. W siedemsetna rocznice urodzin ostatniego Piasta na tronie polskim, ed. J. Maciejewski, T. Nowakowski, Bydgoszcz 2011, p. 204.

111 Annales..., lib. 12 (1445-1461), Cracoviae 2003, p. 253.

112 Zeph 2, 3; Ps 126, 5; see: G. Colzani, Pokora, in: Encyclopedia of Christianity, ed. Krahelska, Warszawa 2010. Witczyk, Kielce 2000, p. 568.

113 J. Le Goff, N. Truong, op. cit., pp. 59-63.Maria Koczerska claims that tears are also an expression of the impulsive emotionality of the Middle Ages, see: eadem, op. cit., p. 112.

114 A. Szulc, Reduc me in memoriam. Wokół nurtu pasyjnego średniowiecznych kazań bernardyńskich, in: Bernardyni na Śląsku..., p. 168.

115 Annales..., lib. 12 (1445-1461), Cracoviae 2003, p. 255.

116 Fr. W. Pazera, op. cit., p. 101; A. Lissowska, op. cit., p. 61; W. Murawiec OFM, op. cit, pp. 292-293.

117 What found expression in iconography, see: A.E. Obruśnik OFM, op. cit., pp. 306-309, 317, 319.

118 See: W. Murawiec OFM, op. cit., pp. $279-280$.
} 
autem impugnacionis die - on the third day of the assault) ${ }^{119}$, the sacred number that appears in the Annals ... in important moments of Christians' life, strengthened the mood ${ }^{120}$. So we have another example of a medieval battle constructed according to the scheme ${ }^{121}$ : infidels, bad people who destroyed the native sacrum $^{122}$, were defeated thanks to divine intervention revealed this time through the actions of God's servant, John of Capistrano ${ }^{123}$. He contributed to the fulfilment of God's justice ${ }^{124}$, which occupies a special place in Długosz's thoughts ${ }^{125}$. The preacher's fight with the infidels was immortalised in iconography. In many artistic imaginations, a figure of a Turk at his feet is visible ${ }^{126}$.

The description of the death of the future saint does not differ from the medieval patterns. Długosz reported that John of Capistrano, regretting the death of Jan Hunyady, fell ill himself. Stones, stomach ache, colitis, fever and general weakness caused him all weak ${ }^{127}$. It is not surprising here that human ailments attributed to John, after all, a medieval saint, and that was what Długosz saw, a man of flesh and blood. Although the preacher was worried about matters of faith, he died peacefully, reconciled with fate. Humility towards divine judgments had to be emphasised this time. His death occurred on October 23, 1456. He was buried in the Franciscan monastery in Ujlak in Hungary (now Ilok in Croatia) ${ }^{128}$. Both the date of death and the place of burial of Capistrano are given by Długosz very accurately ${ }^{129}$. This is where the preacher's dying ends and the posthumous story of the saint begins. The story, however, cannot be written without appropriate accents. So we read about the pleasant and light body of Capistrano after his death and his posthumous healings. Again, prophecy is emphasised, the gift of extraordinary people ${ }^{130}$, which occurred even during the hero's life, and the gift of tears - this is a desirable complement to the image of the saint. And this one is full in Długosz's work. John of Capistrano - a religious, a preacher of the word of God, humble, pious, prudent and wise, a role model, a missionary and a tamer of the infidels, a fighter for divine justice, a miracle worker, a healer, a slayer of the devil - arguments that the reader would recognise that John of Capistrano as an unusual figure.

\footnotetext{
119 Annales..., lib. 12 (1445-1461), Cracoviae 2003, p. 255.

${ }^{120}$ On the symbolism of number three in Christianity see: D. Forstner, op. cit., p. 43; A. Barciak, op. cit., p. 74; C.K. Święcki, Kultura piśmienna w Polsce średniowiecznej X-XII wiek, Warszawa 2010, p. 105.

${ }^{121}$ Cf. P. Żmudzki, Opisy bitew ukazujące wojowników gotowych przyjąć swój los (przykłady stowiańskie XI-XIII w.), in: Sacrum. Obraz i funkcja w społeczeństwie średniowiecznym, ed. J. Pysiak, A. Pieniądz-Skrzypczak, Warszawa 2005, p. 161.

122 See: E. Potkowski, Stereotyp heretyka-innowiercy $w$ piśmiennictwie kaznodziejskim, in: Kultura elitarna a kultura masowa w Polsce późnego średniowiecza, ed. B. Geremek, Wrocław 1978, pp. 122-123 and next.; U. Borkowska, Treści ideowe w dziełach..., p. 17.

123 About the fight for Belgrade see: G. Maron, op. cit., p. 156-158.

124 U. Borkowska, Treści ideowe w dziełach..., p. 128.

125 M. Koczerska, op. cit., p. 113.

${ }^{126}$ M. Jacniacka, Jan Kapistran. II. W ikonografii, in: Encyklopedia katolicka, t. 7, ed. S. Wielgus, Lublin 1997, col. 798, 799; A.E. Obruśnik OFM, op. cit., pp. 318, 322, 325.

127 Annales..., lib. 12 (1445-1461), Cracoviae 2003, p. 269: calculi iliumque pressura, febribus quottidianis et disenterie languore correptus; on the end of life and death of a preacher see: G. Maroń, op. cit., pp. 158-159.

128 A. Lissowska, op. cit., p. 53.

129 Rozbiór krytyczny..., p. 95.

130 B. Geremek, $O$ średniowieczu, p. 425.
} 
Although Jan Długosz did not articulate the matters obvious to him ${ }^{131}$, he clearly tried to convince the reader that the role of saints, also in the late Middle Ages, was unique ${ }^{132}$. So he attributed sanctity to a valued and known, though not yet canonised hero. It seems, therefore, that he did not know the letter of the great preacher to Francis of Barbara of March 14, 1451, in which Capstrano remarked that he was asking not to make him a saint in his lifetime ${ }^{133}$. In the case of the source image of this hero, the truth is intertwined with literary fiction, which is strongly linked to the wish story this time.

\section{John of Capistrano in Jan Długosz's Annales ... Summary}

Jan Długosz in his cards made a presentation of Annales...fifteenth century priest and reformer - Jan Kapistran. My purpose was to show the characteristic this person, something valued by chronicle writers. Długosz used different methods, to convince the reader about the concepts of hero sainthood, for example descriptions such as: famous, reverend, smart - which came from the catalog, which were used by the author many times, symbolical, numbers - three, forty, a hundred, which enforce a belief, that next to Jan amazing things are happening. Miracle making, prediction, healing, gift of tiers most appeared in this source biography. Comparing the preacher to St. Augustine strengthened the belief in the sanctity of the hero.

Keywords: saint, priest, chronicle, miracle, tears

Translated by Artur Stankiewicz

Note about the Author: Dr Barbara Kowalska is an employee of the Jan Długosz University in Częstochowa (Department of Ancient and Medieval History). She specialises in research in the medieval history, especially the history of mentality and the symbolism of medieval culture. She is the author of the book titled Święta Kinga-rzeczywistość i legenda. Studium źródłoznawcze (title in English: Saint Kinga - reality and legend source studies), Cracow 2008 and of many other scientific articles. She is the vice president of the Polish Historical Society Częstochowa Division.

\footnotetext{
131 The text interpreter does not ask what the text says, but what it does not speak of as obvious: U. Eco, op. cit., p. 114.

132 See: A. Vauchez, Święty, in: Człowiek średniowiecza, ed. J. Le Goff, thum. M. Radożycka-Paoletti, Warszawa 2000, pp. 415-428; A. Kuźmiak-Ciekanowska, op. cit., p. 149; M. Cetwiński, Historiografia polska o roli świętych, in: Drogi i rozdroża chrześcijańskiej Europy, ed. U. Cierniak, J. Grabowski, Częstochowa 2003, pp. 185-189.

133 W. Murawiec OFM, op. cit., p. 283.
} 